\title{
IMPLEMENTASI SISTEM LELANG ELEKTRONIK (E-PROCUREMENT) OLEH PEMERINTAH KOTA TANJUNGPINANG
}

\author{
Raja Dachroni ${ }^{1}$, Raja Erafidah ${ }^{2}$, Edward Mandala ${ }^{3}$, Sigit Sepriandi ${ }^{4}$ \\ ${ }^{123}$ Program Studi IImu Pemerintahan, STISIPOL Raja Ali Haji Tanjungpinang \\ ${ }^{4}$ Program Sudi Magister IImu Pemerintahan, Universitas Muhammadiyah Yogyakarta \\ email: dachronijurnal@gmail.com
}

\begin{abstract}
Abstrak
Tujuan penelitian ini untuk melihat bagaimana implementasi sistem e-procurement melalui Unit Layanan Pengadaan secara Elektronik Pemerintah Kota Tanjungpinang, yang telah diadopsi pada tahun 2011. Penelitian ini juga ingin melihat faktor-faktor apa saja yang mempengaruhi implementasi e-procurement. Metode yang digunakan dalam penelitian ini adalah metode campuran, kualitatif dan kuantitatif. Teknik pengumpulan data yang digunakan dalam penelitian ini adalah kuesioner, wawancara dan dokumenter. Sedangkan target dari penelitian ini adalah pihak yang memahami secara detail bagaimana proses penerapan sistem e-procurement di pemerintahan kota Tanjungpinang. Hasil dari penelitian ini adalah bahwa implementasi sistem e-procurement di kota Tanjungpinang telah berjalan efektif dengan nilai indeks efektivitas 3,13. Parameter yang berkontribusi pada efektivitas kejelasan implementasi perencanaan e-procurement $(3,32)$, tujuan dan sasaran yang jelas $(3,28)$, jenis sistem situs web $(3,26)$, sumber daya manusia $(3,25)$, infrastruktur dan jaringan $(3,01)$, efisiensi dan efektifitas $(2,96)$ regulasi adalah parameter terendah dengan nilai 2,84 . Meskipun demikian, implementasi e-procurement di pemerintah Kota Tanjungpinang telah dilakukan secara efektif, tetapi masih ditemukan adanya pengaruh pollitik dalam sistem eprocurement tersebut. Namun dengan kemauan politik pemerintah kota Tanjungpinang yang cukup kuat.
\end{abstract}

Keywords: Implementasi, e-Procurement, LPSE

\begin{abstract}
The purpose of this research to see how the implementation of e-procurement system through Electronic Procurement Service Unit Government of Tanjungpinang city, which had been adopted in 2011. This study also wanted to see the factor which influence eprocurement implementation. The method used in this research is a mixed method, qualitative and quantitative. Data collection techniques used in this research are questionnaires, interviews and documentaries. While the targets of this research is parties who understand in detail how the process of implementing e-procurement system in government of Tanjungpinang city. Results from this research is that the implementation of e-procurement system in Tanjungpinang city has run effective with the effectiveness index value of 3.13. The parameters that contribute to the effectiveness of the implementation clarity of e-procurement planning (3,32), clear objectives and goals $(3,28)$, type of website system $(3,26)$, human resources $(3,25)$, infrastructure and network $(3,01)$, efficiency dan effectivenes $(2,96)$ regulation is the lowest parameter with a value of 2,84 . Even though, $e-$ procurement implementation in government of Tanjungpinang City have been done effectively, but still found there was pollitic influenced in those e-procurement system. But with the political will of the Tanjungpinang city government that is strong enough.
\end{abstract}

Keywords: Implementation, e-Procurement, LPSE 


\section{PENDAHULUAN}

Sikap pemerintah dalam memperkecil dan berusaha memangkas praktik KKN dalam pengadaan barang dan jasa di Indonesia dibuktikan dengan dikeluarkannya Peraturan Presiden No.54 Tahun 2010 yang secara tidak langsung menyatakan bahwa pelaksanaan lelang secara elektronik atau disebut e-procurement sudah harus menjadi sebuah kewajiban yang harus dimulai pada Tahun 2012. Sebuah majalah pengadaan kredibel menjelaskan bahwa, pemerintah Indonesia dengan menerbitkan Inpres No.17 Tahun 2011 tentang aksi pencegahan dan pemberantasan korupsi pada tahun 2012 memiliki poin yang semakin mengkuatkan pada tahun anggaran 2012 sekurang kurangnya 75\% dari seluruh belanja Kementerian/Lembaga (K/L) dan $40 \%$ belanja pemerintah daerah yang dipergunakan untuk pengadaan barang dan jasa wajib menggunakan e-procurement (Dan 2010).

Namun proses adopsi e-procurement di Pemerintah Kota Tanjungpinang juga bukan tanpa masalah. Ada beberapa tantangan, hambatan yang harus dihadapi oleh Layanan Pengadaan Secara Elektronik (LPSE) Kota Tanjungpinang yakni: pertama, adalah persoalan keterbatasan Sumber Daya Manusia sebagai panitia pengadaan. Kedua adalah persoalan masih kurangnya sarana dan prasarana yang dimiliki oleh Unit Layanan Pengadaan seperti komputer, printer sebagai peralatan pendukung sistem pengadaan secara elektronik, serta bangunan gedung pada Unit Layanan Pengadaan (ULP) yang belum memadai.

Ketiga adalah masalah adanya beberapa proyek yang gagal lelang, diantaranya adalah pada paket pekerjaan belanja modal pengadaan perlengkapan kesehatan, paket pekerjaan belanja tambahan reagensi laboratorium, paket pekerjaan belanja obat obatan generik, paket pekerjaan belanja bibit ternak dan lain lain. Hal ini disebabkan karena pada umumnya karena perusahaan yang memasukkan penawaran masih kurang dari 3 (tiga) perusahaan sehingga proses lelang tidak bisa dilanjutkan. Keempat, adanya persoalan keterbatasan daya listrik yang dikhawatirkan akan mengganggu proses lelang karena setiap hari rata-rata PLN melakukan pemadaman sekitar 3-6 jam yang dilakukan secara bergilir.

Selain keempat masalah tersebut juga masih ada masalah lain yaitu adanya indikasi kolusi pada tahapan lelang proyek pembangunan pelantar beton, di Sei Jang Bukit Bestari Kota Tanjungpinang dengan total nilai proyek 456 juta rupiah, 
Sejak awal pembangunan pihak kontraktor sudah mengurangi spesifikasi besi ulir yang digunakan dalam pembuatan kerangka penampang kolom pelantar tersebut. (Wartaindonesia news 24 November 2014). Berdasarkan fenomena dan beberapa tantangan, masalah dan hambatan tersebut, penelitian ini mencoba untuk memberikan solusi terhadap permasalahan tersebut.

E-procurement merupakan pengembangan konsep e-government, dimana $e$ government menurut UNDP (Sugandi 2011) adalah "penggunaan tekhnologi informasi pergerakan informasi dikarenakan keterbatasan fisik seperti kertas dan sistem berdasarkan fisik secara tradisional melalui penggunaan teknologi secara terus menerus untuk mengakses dan mengirimkan pelayanan pemerintah untuk dimanfaatkan oleh warga negara".

Sementara itu Purwanto et al (2008) menjelaskan bahwa e-procurement adalah proses pembelian barang dan jasa yang diperlukan bagi kebutuhan operasional secara elektronik. Di lain pihak, menurut Groom dan Jones (Purwanto et al 2008) pengertian e-procurement adalah sistem data base yang terintegrasi dan area luas yang berbasis internet dengan jaringan sistem komunikasi dalam sebagian atau seluruh pembelian. Sementara Neef (Purwanto et al 2008) menyatakan bahwa e-procurement sebagai pengadopsian sistem berbasis internet dalam proses pembelian.

Indikasi tersebut merupakan salah satu faktor yang dapat mengurangi nilai keefektifan penerapan e-procurement dalam pengadaan barang/jasa. Maka dari itu, diperlukan pengawasan atau pemantauan yang intensif dari masyarakat dan LSM seperti ICW (Indonesia Corruption Watch). Perlunya pengawasan masyarakat dan LSM tersebut, karena dua aktor tersebut memiliki peran yang dianggap paling bagus dan netral dalam pengadaan barang/jasa, sehingga tujuan e-procurement nantinya dapat berjalan dengan baik dan tanpa ada kecurigaan (Rossita et al. 2007).

Proses implementasi sistem e-procurement merupakan sebuah jalinan sistem yang saling terkait, Sistem e-procurement memiliki lima komponen dalam implementasinya yaitu pembuatan kebijakan dan manajemen, regulasi pengadaan, pemberian kewenangan dan pemenuhan, operasionalisasi fungsi e-procurement public, dan umpan balik (Thai 2001). Kemudian Thai menjelaskan bahwa hubungan lima komponen tersebut sebagai berikut (Thai 2001): 
Dimana regulasi pengadaan diterbitkan oleh pembuat kebijakan dan juga manajemen pengadaan yang kemudian menjadi kerangka institusional terhadap penyelenggara e-procurement dengan profesional (yaitu pejabat pembuat kontrak, pembeli, dan panitia pengadaan) dan juga manajer program yang melaksanakan kewenangan mereka dan juga pemenuhan program dan proyek pengadaan dan akuntabilitas diberikan kepada pembuat kebijakan dan juga manajemen pengadaan. Hubungan antara keempat elemen atau kotak dihubungkan dengan anak panah. Terakhir, umpan balik akan merujuk pada pembuat kebijakan dan manajemen pengadaan sebagai penilaian positif dan meningkatkan dalam melaksanakan regulasi, penyerahan wewenang dan juga pemenuhan, selain itu juga mengarah kepada penyelenggara pengadaan dan juga panitia sebagai penilaian dan peningkatan operasionalisasi pengadaan". Kemudian Thai menyimpulkannya pada gambar berikut:

\section{Gambar 1.1}

\section{Sistem e-procurement}

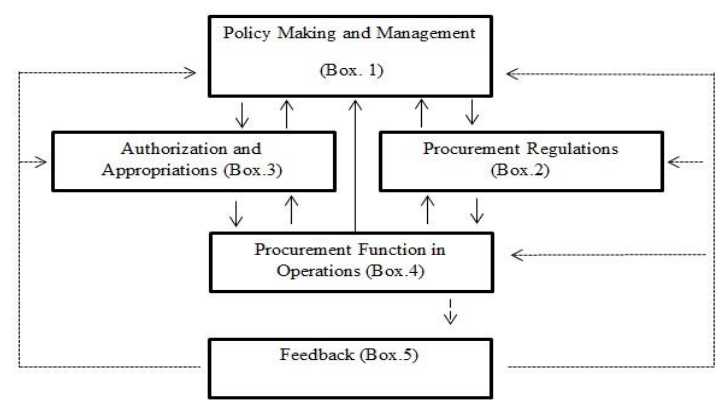

Sumber: (Thai 2001)

Dari beberapa tantangan, masalah dan hambatan tersebut, dan dengan pemaparan teori yang telah dibahas, maka penelitian ini akan dilakukan untuk meneliti secara komprehensif bagaimana implementasi sistem pengadaan secara elektronik pada Layanan Pengadaan Secara Elektronik Kota Tanjungpinang.

\section{METODE PENELITIAN}

Jenis penelitian ini adalah dengan menggunakan metode campuran dominan kualitatif dan less kuantitatif. Metode penelitian campuran (mix method research) adalah suatu disain penelitian yang didasari asumsi tentang cara pengumpulan dan 
menganalisis data serta perpaduan pendekatan kuantitatif dan kualitatif melalui beberapa fase penelitian (John.W Creswell 2012). Mixed method research berfokus pada pengumpulan dan analisis data serta memadukan antara data kuantitatif dan kualitatif yang mana premis sentral yang dijadikan dasar mix methode researh adalah menggunakan kombinasi pendekatan kuantitatif dan kualitatif untuk menemukan hasil penelitian yang lebih baik dibanding menggunakan salah satu pendekatan saja.

Penelitian kuantitatif adalah cara untuk memperoleh ilmu pengetahuan atau memecahkan masalah yang dihadapi dan dilakukan dengan cara hati-hati dan sistematis, dan data-data yang dikumpulkan berupa rangkaian atau kumpulan angka-angka (Toto Syatori Nasehuddin 2012). Penelitian kualitatif adalah" penelitian yang bermaksud untuk memahami fenomena tentang apa yang dialami oleh subjek penelitian secara holistik dan dengan cara deskripsi dalam bentuk kata-kata dan bahasa (Moleong 2007).

Adapun pendekatan penelitian kuantitatif yang digunakan dalam penelitian ini adalah dengan cara metode survei. Penelitian dengan metode survei adalah penelitian yang mengambil sampel dari satu populasi dan menggunakan kuesioner sebagai alat pengumpul data yang pokok (Sofian 1989). Senada dengan hal tersebut, Prasetyo dan Jannah (2012) juga mengungkapkan bahwa penelitian dengan metode survei adalah "penelitian yang mengunakan kuesioner sebagai instrument penelitian".

Adapun pendekatan eksplanasi penelitian ini adalah dengan menggunakan penelitian deskriptif. Dimana hasil dari kuantifikasi hasil survei akan dieksplanasikan secara deskriptif. Menurut Prasetyo dan Jannah (2012) bahwa penelitian deskriptif ini adalah sebuah penelitian untuk memberikan gambaran yang lebih detail mengenai suatu gejala atau fenomena.

Pada tahap pertama penelitian ini akan dilakukan dengan cara kuantitatif dengan melakukan penelitian dengan pendekatan survei, kemudian setelah pengambilan data kuantitatif selesai dilakukan maka tahap selanjutnya adalah dengan melakukan penelitian dengan metode kualitatif.

Implementasi Sistem e-procurement pada Layanan Pengadaan Secara Elektronik (LPSE) Kota Tanjungpinang diukur dengan menggunakan beberapa konsep dan parameternya sebagai berikut: 
1. Kepemimpinan dan kelembagaan dengan parameter:

a. Adanya regulasi

b. Adanya kejelasan dalam perencanaan e-procurement

c. Dukungan sumber daya manusia

2. Tujuan dengan parameter:

a. Tujuan yang jelas dalam kebijakan/ regulasi e-procurement.

3. Fungsionalitas dengan parameter:

a. Dukungan infrastruktur dan jaringan

b. Tipe Sistem website

4. Kinerja dengan parameter:

a. Efesiensi dan efektifitas

\section{Teknik Pengumpulan Data}

Dalam penelitian ini teknik pengumpulan datanya akan menggunakan instrumen penelitian yang disebut dengan kuesioner dimana ditampilkan beberapa pernyataan dimana responden akan menjawab pernyataan tersebut. Kuesioner yang digunakan dalam penelitian ini adalah kuesioner Dengan pertanyaan berbentuk rating scale dimana pertanyaan yang diikuti dengan jawaban yang bertingkat tingkat (Toto Syatori Nasehuddin 2012). Alat pengumpul datanya adalah serangkaian daftar pertanyaan (kuesioner) yang telah disusun secara terstruktur. Dalam penelitian ini kuesioner akan disebarkan kepada:

1. Kepala Bagian Pembangunan

2. DPRD Kota Tanjungpinang

3. LPSE Kota Tanjungpinang

4. Unit Layanan Pengadaan (ULP) Kota Tanjungpinang

5. Rekanan / Penyedia Barang dan Jasa

\section{Teknik Wawancara}

Wawancara adalah percakapan dengan maksud tertentu yang dilakukan oleh dua pihak yaitu pewawancara yang mengajukan pertanyaan dan terwawancara yang memberikan jawaban atas pertanyaan itu (Moleong 2007). Dalam penelitian ini akan dilakukan wawancara terhadap: 
1. Kepala Bagian Pembangunan

2. Anggota DPRD Kota Tanjungpinang

3. Perwakilan dari LPSE Kota Tanjungpinang

4. Perwakilan dari ULP Kota Tanjungpinang

5. Perwakilan dari Rekanan (Penyedia Barang dan Jasa)

\section{Teknik Dokumentasi}

Dokumentasi adalah pengambilan data yang diperoleh melalui dokumen dokumen atau literatur yang berkaitan dengan implementasi e-procurement di Kota Tanjungpinang. Dalam tekhnik Dokumentasi maka akan ada dokumen yang akan menjadi data bagi penelitian. Menurut Guba dan Lincoln (dalam Moleong 2007) mengatakan dokumen adalah bahan tertulis atau film. Dokumen sudah lama digunkaan dalam penelitian sebagai sumber data karena dalam banyak hal.

Dalam hal ini, maka dokumen yang akan digunakan adalah data yang sifatnya tertulis ataupun terekam yang memiliki keterkaitan dengan penelitian. Dokumen tersebut seperti data atau arsip yang terkait dengan implementasi $e$ procurement di Kota Tanjungpinang.

\section{Teknik Analisis Data}

Adapun tekhnik analisis data pada penelitian kuantitatif adalah dimulai dari proses pengkodean data, kemudian berlanjut pada pengentrian data, pembersihan data, penyajian data, dan analisis data (Bambang, Jannah, 2012).

1. Pengkodean data

Pada tahap ini data yang telah terkumpul pada kuesioner diberi kode sesuai dengan skor tertentu sesuai dengan kriteria yang telah ditentukan. Kemudian data tersebut diklasifikasi satu persatu sesuai dengan dimensi pengukuran pada penelitian tersebut dan kemudian diberi skor pada masing masing dimensi. Adapun teknik pengkodean yang digunakan adalah dengan menggunakan skala ordinal/ skala likert sebagai berikut III berikut: Oleh karena itu pada penelitian ini teknik analisis data lebih rinci adalah sebagai berikut: 
Tabel 1. Penentuan Skor Ordinal Responden

\begin{tabular}{cc}
\hline Skor kategori indeks efektifitas & Kategori \\
\hline $1,00-1,75$ & Tidak efektif \\
$1,76-2,50$ & Kurang efektif \\
$2,51-3,25$ & Efektif \\
$3,26-4,00$ & Sangat efektif \\
\hline
\end{tabular}

2. Pengentrian Data

Data yang telah diklasifikasikan sesuai dengan dimensi penelitian dan telah dihitung jumlah skornya kemudian dientri ke dalam komputer.

3. Pembersihan data

Pada tahap ini data yang telah diklasifikasikan dan diberi skor serta dihitung maka dipastikan kembali kebenarannya dan keakuratan hitungan dari data tersebut.

4. Penyajian Data

Data yang telah dipastikan benar klasifikasi dan skoringnya kemudian disajikan dalam bentuk tabulasi, grafik atau gambar. Hal ini akan memudahkan proses selanjutnya yaitu penganilasaan data.

5. Analisis Data

a. Pengukuran Indeks

Adapun teknik scoring yang digunakan adalah teknik skala indek.

Indek efektifitas $=\underline{\text { Total dari nilai persepsi per unsur } \times \text { Nilai penimbang }}$

Total unsur yang terisi

Selanjutnya nilai indeks akan dikategorikan berdasarkan data berikut:

Tabel 2. Skor Kategori Nilai Indeks

\begin{tabular}{cc}
\hline KRITERIA & $\begin{array}{c}\text { PERNYATAAN } \\
\text { (SKOR) }\end{array}$ \\
\hline Sangat setuju & 4 \\
Setuju & 3 \\
\hline
\end{tabular}




\begin{tabular}{cc}
\hline Kurang setuju & 2 \\
Tidak setuju & 1 \\
\hline
\end{tabular}

b. Uji Validitas

Data yang telah disajikan dalam bentuk tabulasi, maka tahap pertama adalah melakukan uji validitas untuk mengukur valid atau tidaknya pertanyaan yang digunakan untuk mengukur semua parameter penelitian ini. Uji validitas ini dilakukan dengan menggunakan rumus produk moment yaitu dengan rumus sebagai berikut :

$$
r_{x y}=\frac{N \cdot \sum x \cdot y-\left(\sum x\right)\left(\sum y\right)}{\sqrt{\left[N \cdot \sum X^{2}-(\Sigma X)^{2}\right]\left[N \cdot \sum Y^{2}-\left(\sum Y\right)^{2}\right]}}
$$

c. Uji Reliabilitas

Tahap selanjutnya dilakukan uji reliabilitas untuk mengukur tingkat konsistensi alat ukur, dengan menggunakan rumus croanbach's Alpha sebagai berikut :

$$
r_{11}=\left[\frac{k}{k-1}\right]\left[1-\frac{\sum \sigma_{b}^{2}}{V_{1}^{2}}\right] \quad \ldots \ldots \ldots{ }^{2}
$$

Selanjutnya setelah dilakukan penghitungan, maka penelitian terhadap implementasi e-Procurement di Kota Tanjungpinang ini dapat dihipotesiskan sebagai berikut:

Tabel 3. Hipotesis Penelitian

\begin{tabular}{cl}
\hline Hipotesis & \multicolumn{1}{c}{ Pernyataan } \\
\hline $\mathbf{H}_{\mathrm{o}}$ & $\begin{array}{l}\text { Implementasi e-procurement di Kota Tanjungpinang } \\
\text { dikategorikan efektif }\end{array}$ \\
$\mathrm{H}_{\mathbf{a}}$ & $\begin{array}{l}\text { Implementasi e-procurement di Kota Tanjungpinang } \\
\text { dikategorikan tidak efektif }\end{array}$ \\
\hline
\end{tabular}

\section{PEMBAHASAN}

Sebelum masuk pada pembahasan hasil penelitian, adapun responden dalam penelitian ini adalah 30 responden. Adapun karakteristik responden dilihat dari jenis kelamin lebih banyak laki-laki dibandingkan perempuan, seperti yang dapat dilihat pada tabel di bawah ini. 
Tabel 4. Karakteristik Responden Berdasarkan Jenis Kelamin

\begin{tabular}{ccc}
\hline $\begin{array}{c}\text { Jenis } \\
\text { Kelamin }\end{array}$ & Jumlah & Persentase \\
\hline Laki-laki & 23 & $77 \%$ \\
Perempuan & 7 & $23 \%$ \\
\hline TOTAL & $\mathbf{3 0}$ & $\mathbf{1 0 0 \%}$ \\
\hline \multicolumn{2}{c}{ Sumber: olahan data primer }
\end{tabular}

Selanjutnya jika dilihat berdasarkan rentang usia, responden terbanyak berada di rentang usia antara 36-44 tahun. Untuk lebih jelasnya dapat dilihat pada tabel di bawah ini.

\section{Tabel 5. Karakteristik Responden Berdasarkan Usia}

\begin{tabular}{ccc}
\hline Usia & Jumlah & Persentase \\
\hline $18-26$ & 3 & $10 \%$ \\
$27-35$ & 10 & $33 \%$ \\
$36-44$ & 15 & $50 \%$ \\
$45-53$ & 2 & $7 \%$ \\
$54-60$ & 0 & $0 \%$ \\
\hline TOTAL & $\mathbf{3 0}$ & $\mathbf{1 0 0} \%$
\end{tabular}

Sumber: olahan data primer

Selanjutnya berdasarkan karakteristik responden tersebut penelitian ini menemukan bahwa pelakasanaan e-procurement di Kota Tanjungpinang dinilai telah berjalan dengan efektif. Implementasi sistem e-procurement di Kota Tanjungpinang dapat dikategorikan berjalan dengan efektif, dimana tingkat indeks efektivitas implementasi sistem e-procurement memperoleh nilai 3,12 yang masuk dalam kategori efektif (lihat tabel 6).

Faktor faktor yang mempengaruhi juga dinilai indeks efektivitas pada setiap parameternya. Parameter adanya kejelasan perencanaan e-procurement memperoleh hasil yang sangat efektif dengan nilai 3,32 (lihat diagram 1), parameter tujuan yang jelas dalam kebijakan regulasi e- procurement memiliki nilai indeks 3,28 (lihat diagram 2), parameter type system website memiliki indeks 3,26 (lihat diagram 3), parameter dukungan sumber daya manusia memiliki nilai indeks 3,25 (lihat 
diagram 4), parameter dukungan infrastruktur dan jaringan 3,01 (lihat diagram 5), parameter efesiensi dan efektivitas 2,9 (lihat diagram 6) dan parameter regulasi memiliki indeks efektivitas terendah yakni 2,84 (lihat diagram 7).

\section{Diagram 1}

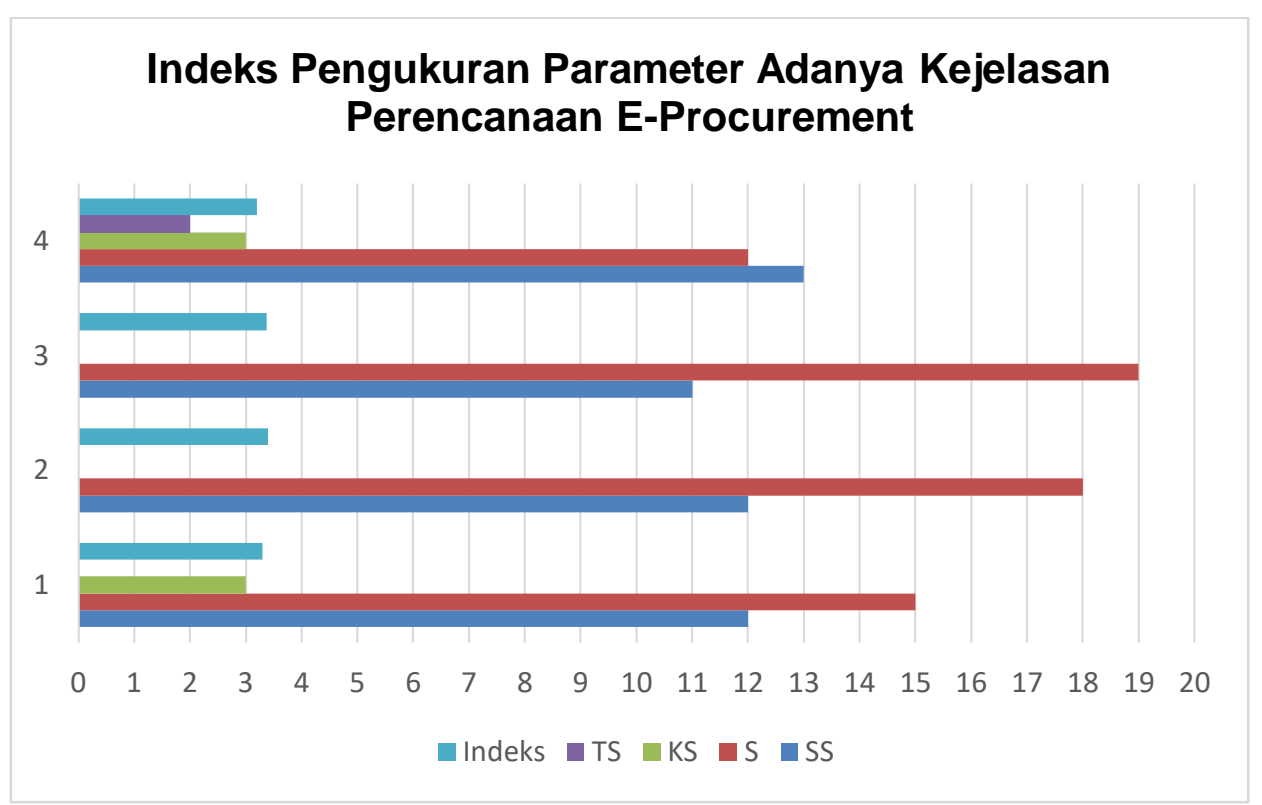

\section{Diagram 2}

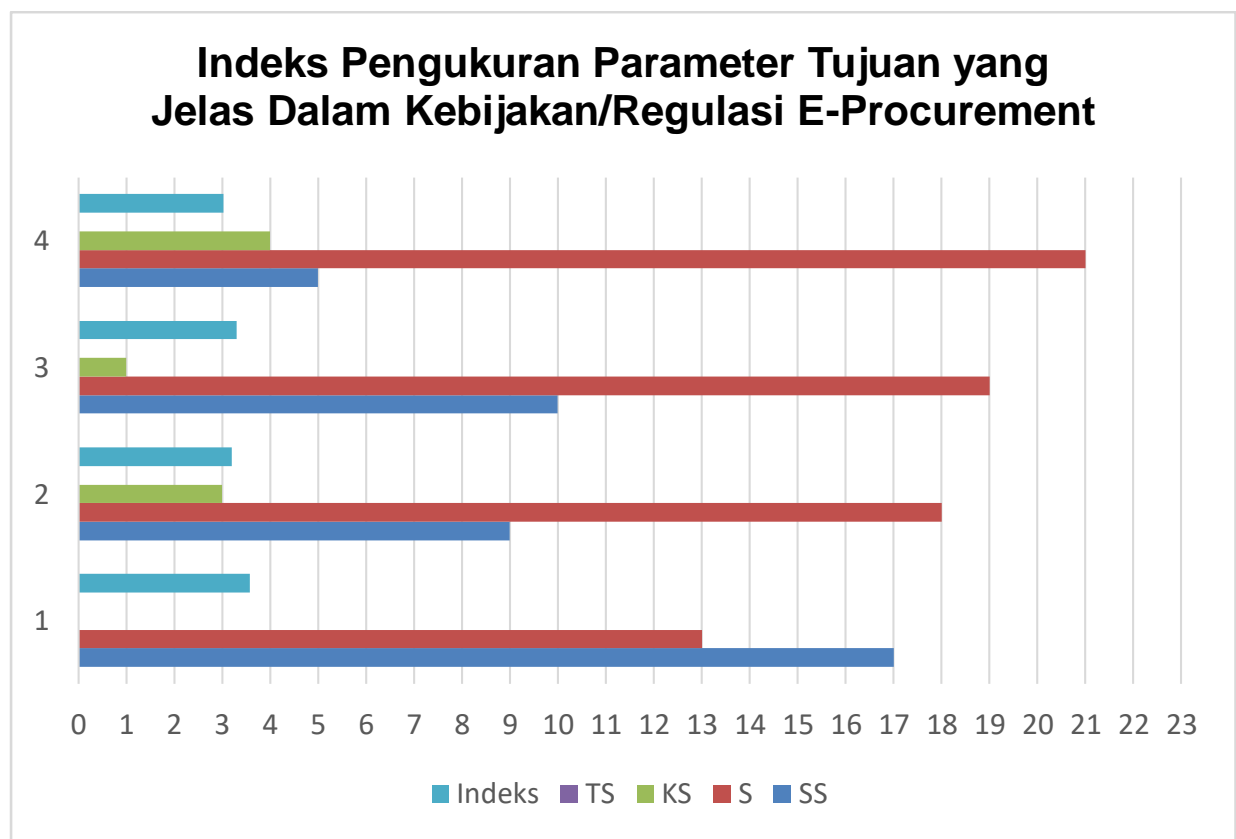




\section{Diagram 3}

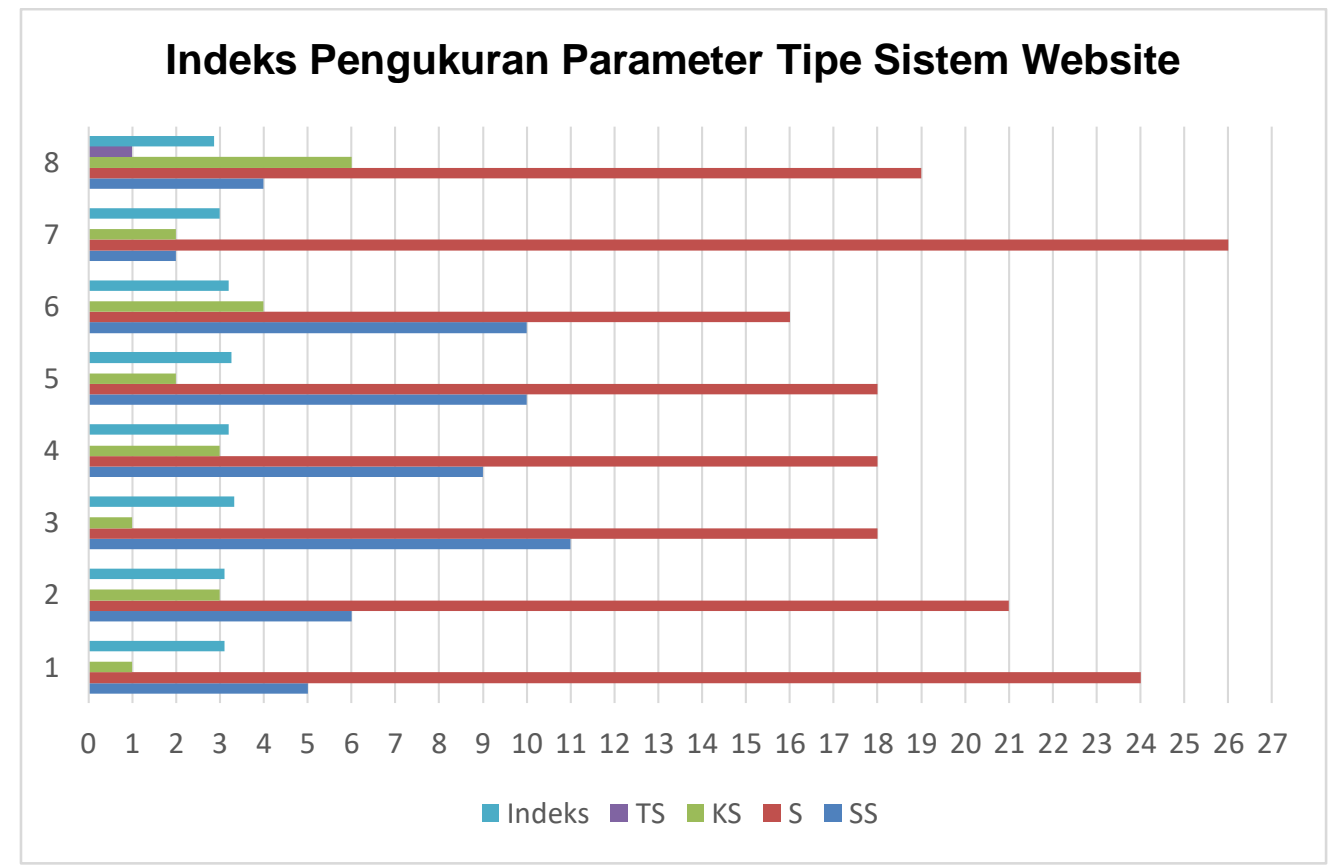

\section{Diagram 4}

Indeks Pengukuran Parameter Dukungan Sumber

Daya Manusia

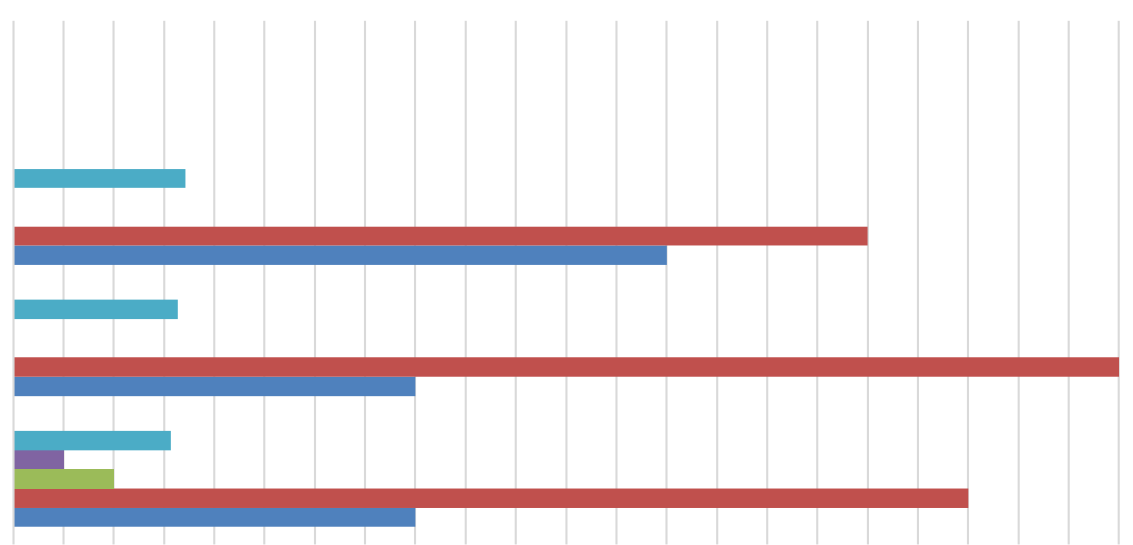

$\begin{array}{lllllllllllllllllllllllll}0 & 1 & 2 & 3 & 4 & 5 & 6 & 7 & 8 & 9 & 10 & 11 & 12 & 13 & 14 & 15 & 16 & 17 & 18 & 19 & 20 & 21 & 22 & 23 & 24\end{array}$

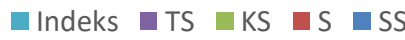




\section{Diagram 5}

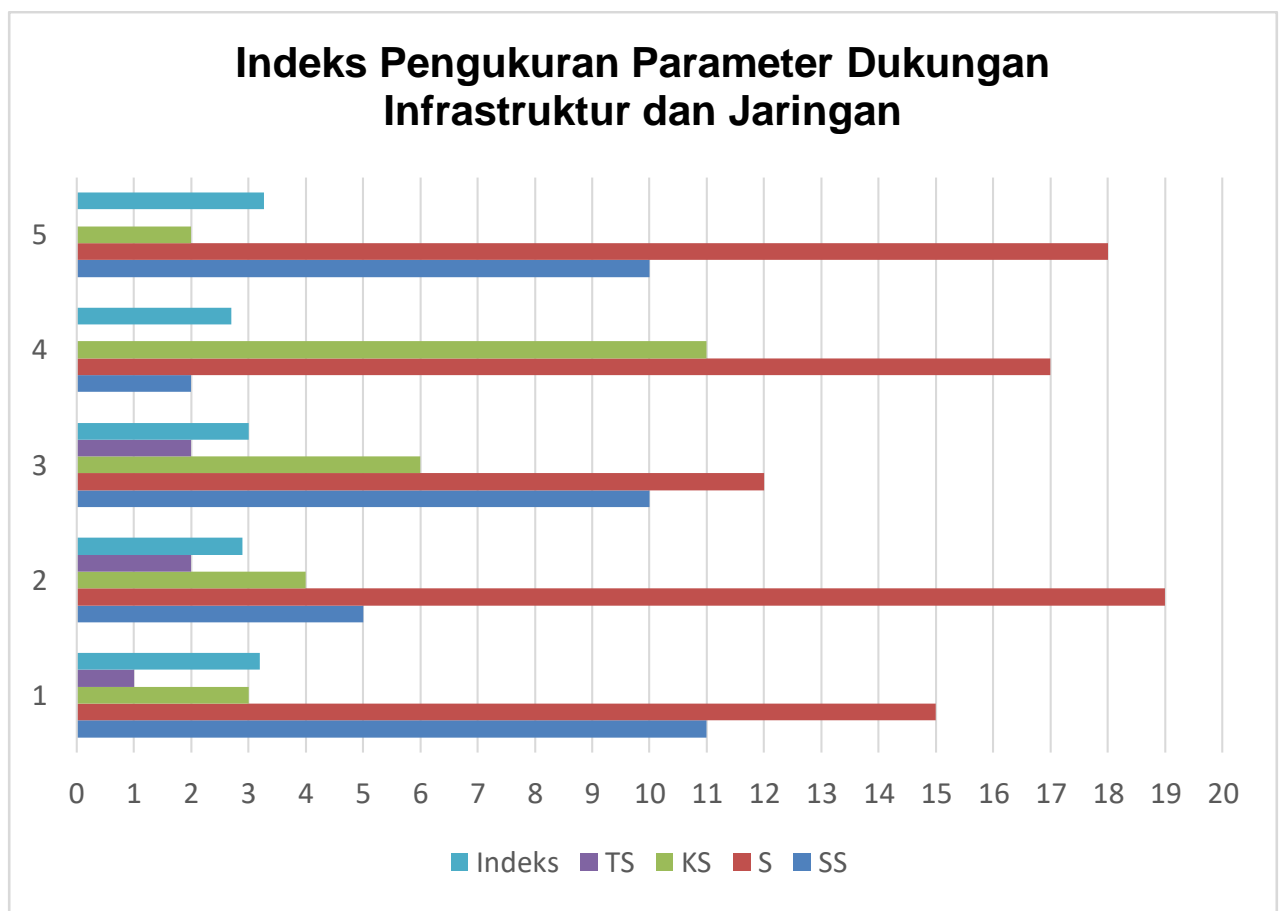

\section{Diagram 6}

Indeks Pengukuran Parameter Efesiensi dan Efektivitas

4

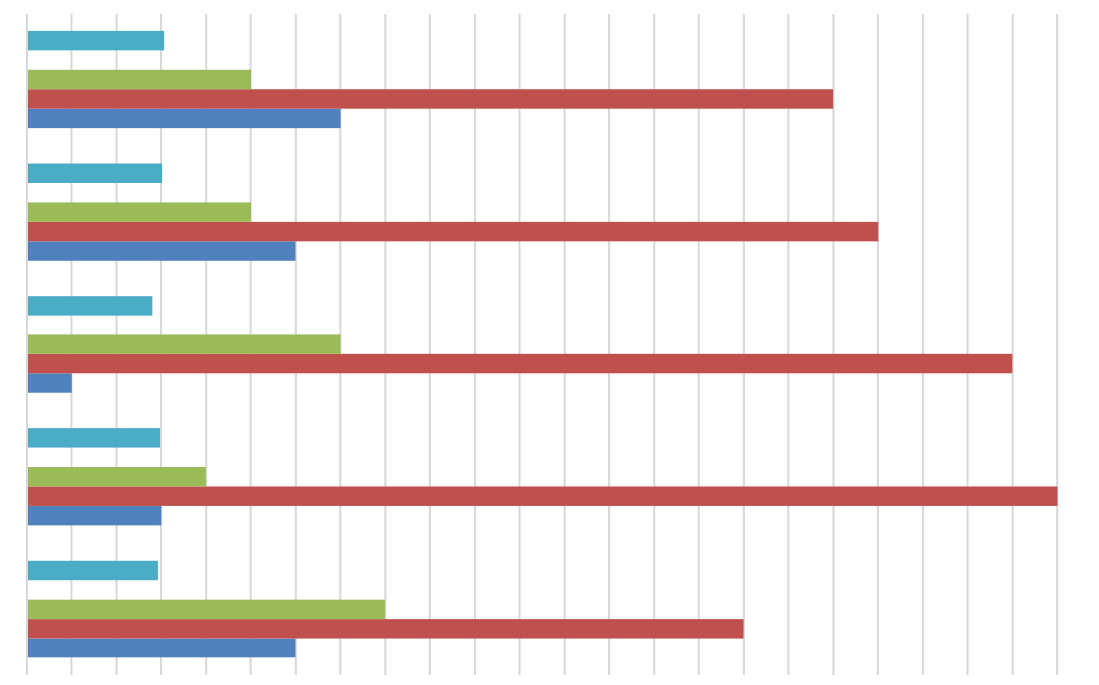

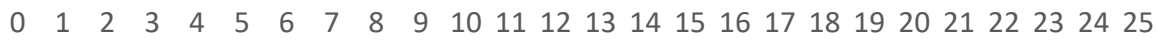

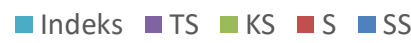




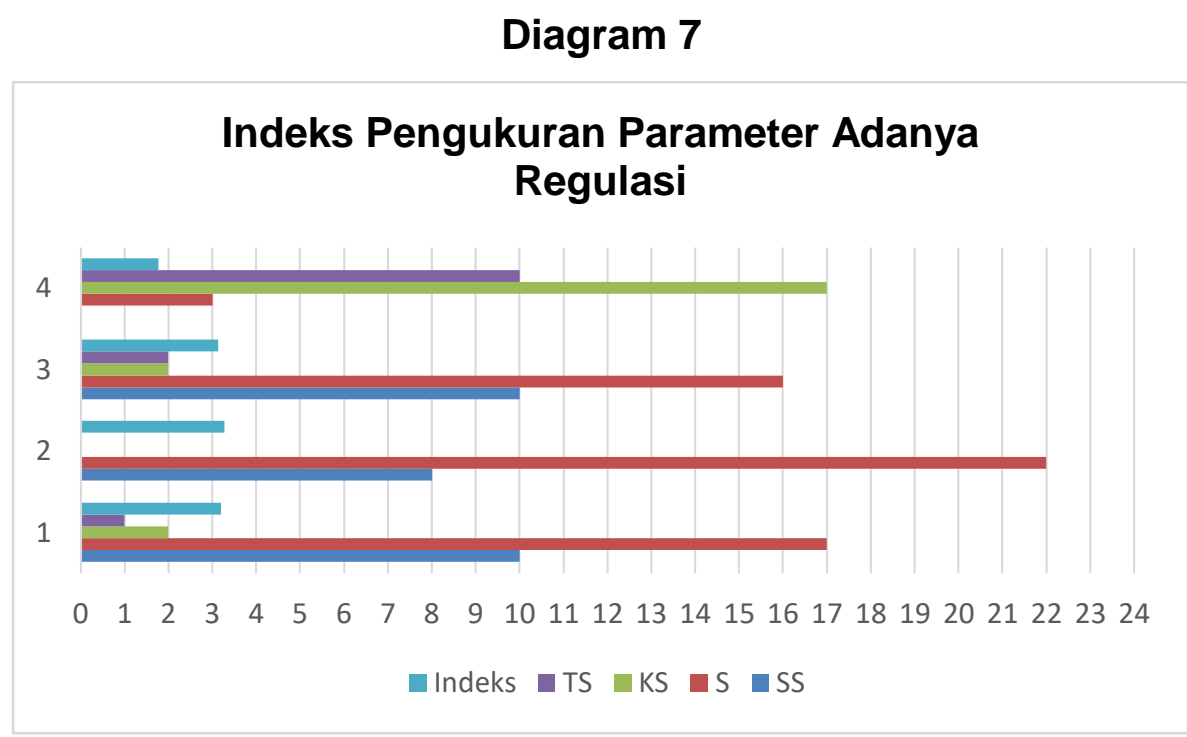

Sumber: data diolah penulis

Berdasarkan keseluruhan indeks pengukuran tersebut, maka hasil pengukuran dapat dilihat pada tabel 6 berikut yang memaparkan keseluruhan pengukuran indeks.

Tabel 6. Daftar Indeks Efektivitas Parameter dari Tingkat Terbesar Sampai Terkecil

\begin{tabular}{clc}
\hline No & \multicolumn{1}{c}{ Parameter } & $\begin{array}{c}\text { Nilai } \\
\text { Indeks }\end{array}$ \\
\hline 1 & Adanya Kejelasan Perencanaan E-Procurement & 3,32 \\
2 & Tujuan yang Jelas dalam Kebijakan/Regulasi E- & 3,28 \\
& Procurement & \\
3 & Tipe Sistem Website & 3,26 \\
4 & Dukungan Sumber Daya Manusia & 3,25 \\
5 & Dukungan Sistem Infrastruktur dan Jaringan & 3,01 \\
6 & Efesiensi dan Efektivitas & 2,96 \\
7 & Adanya Regulasi & 2,84 \\
\hline \multicolumn{2}{c}{$\quad$ Total Indeks } \\
\multicolumn{2}{c}{ Kategori Nilai Indeks Implementasi Sistem E- } \\
\multicolumn{2}{c}{ Procurement } \\
\multicolumn{2}{c}{ Sumber: data diolah penulis } \\
\hline
\end{tabular}

Implementasi e-procurement di Kota Tanjungpinang memang sudah berjalan dengan sangat baik, dimana beberapa prestasi pernah diraih oleh Pemerintah Kota Tanjungpinang dan pada penelitian inipun telah ditemukan data dan fakta yang menunjukkan hal tersebut, namun dengan efektifnya implementasi e-procurement di Kota Tanjungpinang tidak menutup kemungkinan adanya pengaruh proses politik 
dalam proses implementasi e-procurement. Namun dengan politicall will yang cukup kuat dari pemerintah kota Tanjungpinang, maka proses politik yang selalu berkonotasi dengan kepentingan dan permainan yang mengarah pada penyimpangan dapat diminimalisir.

Jika dibandingkan dengan Unit Layanan Pengadaan LPSE Pemprop Kepri Provinsi Kepulauan Riau lokal Kebijakan Pemerintah sistem mengadopsi eprocurement berdasarkan semangat pemerintah daerah untuk mencapai bersih, transparan, dan akuntabel untuk mencapai pemerintahan yang baik. Adopsi sistem e-procurement yang dilakukan oleh Pemerintah Provinsi untuk mengurangi indikasi penyimpangan dan praktik korupsi dalam proses pengadaan. Dukungan untuk sistem e-procurement di Provinsi Kepulauan Riau sangat kuat, terutama oleh provinsi DPRD Kepulauan Riau, bahkan pada tahun 2014 Unit Layanan Pengadaan (ULP) yang merupakan bagian dari 100 implementasi e-procurement akan ditingkatkan ke Badan Layanan Pengadaan (BLP). Pemerintah Provinsi Provinsi Kepulauan Riau tidak lari setengah hati dan melanjutkan kebijakan Pemerintah Pusat yang terkait dengan Electronic Procurement System (SPSE), bukti untuk menetapkan lembaga yang akan mendukung pelaksanaan sistem e-procurement seperti membangun Elektronik unit Layanan Pengadaan (LPSE) kemudian mendirikan unit Layanan Pengadaan (ULP) dan pada tahun 2014, kelembagaan ULP akan ditingkatkan ke Layanan Pengadaan Badan (BLP).

Dukungan untuk adopsi kebijakan sistem e-procurement semakin kuat, tidak hanya didukung oleh Parlemen dan Pemerintah Provinsi Provinsi Kepulauan Riau sebagai pembuat kebijakan, tetapi juga didukung oleh birokrasi di bawahnya. Saat ini, semua tentang pendidikan yang diperlukan untuk pengadaan barang dan jasa dengan sistem e-procurement kecuali untuk pengadaan barang dan jasa dibawah nilai yang seharusnya terbuka ditenderkan, maka masih menggunakan sistem penunjukan langsung akan, tetapi untuk nilai yang telah ditetapkan dalam aturan harus ditender terbuka harus menggunakan sistem e-procurement. Seluruh pendidikan harus menyajikan Rencana Pengadaan Umum (RUP) melalui website LPSE untuk melakukan pengumuman lelang terbuka dan proses lelang terbuka yang dilakukan sesuai dengan prosedur LPSE ini.

Semua mendukung kebijakan melahirkan beberapa kebijakan yang kemudian menjadi dasar dalam melaksanakan sistem e-procurement di Provinsi Kepulauan 
Riau. Kebijakan tersebut antara lain, Peraturan Gubernur Nomor 5 Tahun 2008 tentang Pedoman Elektronik Pemerintah Pengadaan Barang dan Jasa dalam Provinsi Riau Kepulauan, yang Nota Kesepahaman antara Lembaga Pengadaan Barang/Jasa Pemerintah (LKPP) dengan Gubernur Kepulauan Riau No.03/MOU/VII/2008 tentang Pelaksanaan Kerjasama SPSE proses Pengadaan Nasional dan keputusan Gubernur Kepulauan Riau No.2 Tahun 2012 tentang Kelompok Kerja unit Layanan Pengadaan Secara Elektronik (LPSE) Provinsi Kepulauan Riau (Setyadiharja et al. 2014).

\section{KESIMPULAN}

Berdasarkan penelitian yang telah dilakukan maka dapat diambil kesimpulan bahwa implementasi sistem e-procurement di Kota Tanjungpinang dapat dikategorikan berjalan dengan efektif, dimana tingkat indeks efektivitas implementasi sistem eprocurement memperoleh nilai 3,12 yang masuk dalam kategori efektif. Faktor-faktor yang mempengaruhi juga dinilai indeks efektivitas pada setiap parameternya. Parameter adanya kejelasan perencanaan e-procurement memperoleh hasil yang sangat efektif dengan nilai 3,32, parameter tujuan yang jelas dalam kebijakan regulasi $e$ - Procurement memiliki nilai indeks 3,28, parameter type system website memiliki indeks 3,26 , parameter dukungan sumber daya manusia memiliki nilai indeks 3,25, parameter dukungan infrastruktur dan jaringan 3,01, parameter efesiensi dan efektivitas 2,96 dan parameter regulasi memiliki indeks efektivitas terendah yakni 2,84.

Meskipun Implementasi e-procurement di Kota Tanjungpinang dinilai telah berjalan dengan efektif namun masih ditemukan adanya pengaruh faktor politik dalam proses implementasi e-procurement. Namun dengan politicall will yang cukup kuat dari pemerintah kota Tanjungpinang, maka proses politik yang selalu berkonotasi dengan kepentingan dan permainan yang mengarah pada penyimpangan dapat diminimalisir.

\section{REFERENSI}

Bambang, Jannah, P. (2012). Metode Penelitian Kuantitatif (Jakarta). Raja Grafido Persada. 
Dan, M. (2010). Membentuk dan mengembangkan. Lembaga Kebijakan Pengadaan Barang Dan Jasa Pemerintah (LKPP), (5).

John.W Creswell. (2012). Reseach Design Pendekatan Kualitatif, Kuantitatif dan Mixed,. Yogyakarta: Pustaka Pelajar.

Moleong, L. J. (2007). Metodologi Penelitian Kualitatif. Bandung.

Rossita, A., Nurchana, A., Haryono, B. S., Adiono, R., Publik, J. A., Administrasi, F. I., \& Brawijaya, U. (2007). EFEKTIVITAS E-PROCUREMENT DALAM PENGADAAN BARANG / JASA ( Studi terhadap Penerapan E-Procurement dalam Pengadaan Barang / Jasa di Kabupaten Bojonegoro ), 2(2), 2007-2011.

Setyadiharja, R., Budiman, S., Karim, Z. A., Matridi, R. A., Junriana, Ferizone, \& Nurmandi, A. (2014). E-Procurement System Technology: An Analysis in Electronic Procurement Service Unit (LPSE) of Kepulauan Riau Province. The Asian Journal of Technology Management, 7(2), 93-107.

Sofian, E. dan M. S. (1989). Metode Penelitian Survey. Jakarta: LP3ES.

Thai, K. V. (2001). Internasional Handbook of Public Procurement. Francis.

Toto Syatori Nasehuddin. (2012). Metode Penelitian Kuantitatif. Bandung. 